Components and Connections

Principles of Construction 
Dedicated to my teachers Leen Hulsbos and Ruud Sackman 


\section{Components and Connections}

Principles of Construction 
We are grateful to Delft University of Technology for the financial support of this publication and to Ria Stein for her editorial guidance. We acknowledge the help of Tillmann Klein, Jorien Diemel and Henk Mihl for their research, text advice and drawings.

The drawings where made by Jorrit Verduin, Vincent van Sabben, Farhan Alibux, Somayeh Chitchian and Jean-Paul Willemse.

Graphic design concept and cover: Oliver Kleinschmidt, Berlin Layout and typesetting: MEDIEN PROFIS, Leipzig

Translation into English: Taalcentrum Vrije Universiteit, Amsterdam

Subject editing for the English edition: Jörn Frenzel, Berlin

This book is also available in a German edition:

ISBN 978-3-7643-8668-9

Library of Congress Control Number: 2009925662

Bibliographic information published by Die Deutsche Bibliothek Die Deutsche Bibliothek lists this publication in the Deutsche Nationalbibliografie; detailed bibliographic data is available in the Internet at http://dnb.ddb.de.

This work is subject to copyright. All rights are reserved, whether the whole or part of the material is concerned, specifically the rights of translation, reprinting, re-use of illustrations, recitation, broadcasting, reproduction on microfilms or in other ways, and storage in data banks. For any kind of use, permission of the copyright owner must be obtained.

(C) 2009 Birkhäuser Verlag AG

Basel · Boston

P.O.Box 133, CH-4010 Basel, Switzerland

Part of Springer Science+Business Media

Printed on acid-free paper produced from chlorine-free pulp. TCF $\infty$

Printed in Germany

ISBN 978-3-7643-8668-9

987654321

www.birkhauser.ch 